\title{
Tunnistettu ikävoima ravitsee koko työyhteisöä
}

Työterveyslaitos (2011). Ikävoimaa työhön. 359 s.

IHMISEN ELÄMÄ on monien ikäkausien ketju, jossa työelämällä on vahva rooli. Siinä ollaan mukana vuosikymmeniä ja työpaikat ovat nykyisin perheen lisäksi tavallisimpia eri ikäpolvien kohtaamispaikkoja.

Ikään liittyvät kysymykset ovat aina ajankohtaisia. Näin erityisesti nyt, kun elämme EU:n nimeämää Aktiivisen ikääntymisen ja sukupolvien välisen solidaarisuuden eurooppalaista teemavuotta 2012. Sen aikana halutaan korostaa aktiivisen ikääntymisen antamia mahdollisuuksia pysyä työelämässä ja jakaa kokemusperäistä tietoa nuoremmille, jatkaa yhteiskunnassa aktiivisena toimijana ja elää antoisaa elämää mahdollisimman terveenä.

Kun puhutaan iästä, monet alkavat ajatella luonnostaan ikääntymistä, johon liittyy usein runsaasti kielteisiä mielikuvia. Työelämässä niitä tosin yhdistetään nuoriinkin. Työnantajien mielikuvat eri ikäisistä työntekijöistä ovat yleistäen surullisen synkkiä. Vain ikäryhmä 30-40-vuotiaat synnyttää pelkästään myönteisiä mielikuvia. Nuoremmat ovat kokemattomia ja vastuuttomia, vaikka ovatkin energisiä. Vanhempien kokemus, luotettavuus ja työnantajauskollisuus saavat rinnalleen sairautta, kaavoihin kangistumista ja muutosvastarintaa.

Ikä ja ikääntyminen ovat hy- vinkin yksilöllisiä ja moniulotteisia asioita. Ikäystävällisessä työyhteisössä osataan ottaa huomioon ihmisten voimavarat, tukea niiden kehittymistä työuran eri vaiheissa ja hyödyntää eri-ikäisyyden mukanaan tuomaa erilaisuutta. Nuoret ja vanhat voivat tukea monin keinoin onnistuneesti toinen toistensa työkykyä. Siihen tarvitaan tietoa, taitoa, tahtoa ja ikäsidonnaiset tekijät huomioon ottavaa sekä ikätietoutta hyödyntävää henkilöstövoimavarojen johtamista. Sitä on hyvä ikäjohtaminen, joka ei ole mikään irrallinen johtamisoppi.

Työterveyslaitoksen julkaisema Ikävoimaa työhön -kirja tarjoaa yksien kansien välissä rautaisannoksen työelämään liittyvää ikätietoutta. Käsikirjamaisen teoksen kirjoittajina ovat yhdeksän asiantuntijaa: Susanna Lundell, Eva Tuominen, Tomi Hussi, Soili Klemola, Eija Lehto, Elina Mäkinen, Rita Oldenbourg, Tiina Saarelma-Thiel ja Juhani Ilmarinen. Kirja perustuu tutkimustietoon ja kirjallisuusluettelot kunkin luvun lopussa ovat mittavat. Myös kentän ääntä on kuultu laajasti ja näin kirjaan on saatu aitoa työelämän näkökulmaa ja esimerkkejä hyvistä ikäkäytännöistä. Kirjassa on myös pohdittavia kysymyksiä. Ne palvelevat erityisesti Työterveyslaitoksella kehitettyyn Ikävoimaa työhön -valmennuskoulutukseen osallistuvia, mutta sopivat sisällön syventäjiksi muillekin lukijoille.

\section{TYÖKYKYTALO-MALLI HAVAINNOLLISTAA}

Näkökulma ikään nostaa esiin ihmisen kalenteri-iän rinnalla biologisen, psykologisen, sosiaalisen ja työmarkkinaiän sekä ikäasenteet ja ikäsyrjinnän. Moniin tutkimuksiin perustuva Työkykytalo-malli havainnollistaa monimutkaista työkyky-kokonaisuutta neljän kerroksen avulla. Niitä ovat terveys, osaaminen, arvot ja asenteet sekä työ. Talo sijaitsee keskellä jatkuvasti muuttuvaa toimintaympäristöä. Kun työ muuttuu ja voimavarat muuttuvat alati, tasapainon löytäminen ja säilyttäminen työuran eri vaiheissa on haastava tehtävä niin yksilölle kuin työyhteisölle.

Aikuista oppijana käsitellään kirjassa laajasti. Samalla pohditaan, miten tavallisesti myönteisiä arvolatauksia ja mielikuvia sisältävä elinikäinen oppiminen saattaa muodostua työssäkäyvälle uuvuttavaksi elinkautiseksi oppimiseksi, kun työelämästä ja yhteiskunnalta tulevat oppimisvaatimukset eivät käy yksiin yksilön henkilökohtaisen kasvun tarpeiden kanssa. Oppimiseen kannustavaa työtä on pidetty keskeisenä hyvän työn tunnuspiirteenä, mutta lo- 
puttomista oppimisvaatimuksista ja -mahdollisuuksista on tullut myös merkittävä työhyvinvoinnin uhkatekijä. Työmotivaatio ja jaksaminen ovat koetuksella, jos kohtuuttoman suuri osa vapaa-ajasta ja voimavaroista on uhrattava uusien asioiden oppimiseen. Ikääntyvän työntekijän osalta olisikin syytä pysähtyä miettimään, onko todella välttämätöntä oppia kaikki uusi vai voisiko tehtäväkuvaa räätälöidä niin, että työntekijän osaamista voitaisiin käyttää mielekkäämmin sekä hänen että koko työyhteisön kannalta.

Ikääntyminen muuttaa aikahorisonttia ja sitä pidetään ehkä merkittävimpänä eri-ikäisiä erottavana tekijänä. Aikahorisontti määrittää yksilön suhdetta menneeseen ja tu- levaisuuteen. Se on merkityksellinen esimerkiksi silloin, kun työntekijä pohtii ammatillisia tavoitteitaan.

Vastustus on luonnollinen osa mitä tahansa muutosta. Varsinkin ikääntyneitä työntekijöitä pidetään vastarannan kiiskinä. Vastustuksella on kuitenkin myönteinen kääntöpuolensakin. Yleensä se kertoo työntekijän sitoutumisesta organisaatioon. Vastustukseen voi liittyä myös tervettä kriittisyyttä ja kokemuksen tuomaa hiljaista tietoa, jota voidaan hyödyntää muutosten johtamisessa. Ikääntyneitä ei tulisikaan nähdä muutosten jarrumiehinä. Sen sijaan heillä on tärkeä rooli perinteen välittäjänä, jolloin mennyttä kriittisesti tarkastellen voidaan tulevaisuutta hahmottaa realistisemmin.
Organisaatioiden kehittäessä omia ikäjohtamiskäytäntöjään on tärkeää hyödyntää eri toimijoiden asiantuntemusta. Kirjoittajat muistuttavat, että ikäystävällinen työyhteisö perustuu johdon, henkilöstön, työsuojeluorganisaation ja työterveyshuollon joustavalle yhteistyölle. Kaikkien osapuolten tiedon, näkemysten ja kokemusten suunnitelmallinen huomioon ottaminen tukee ikämyönteisen kulttuurin rakentamista. On tärkeää, että osapuolet tunnistavat toistensa roolit ja vastuualueet sekä tietävät kenen puoleen kääntyä missäkin asiassa ja miten asioista tiedotetaan.

Marjo Rautvuori

FM, toimittaja 